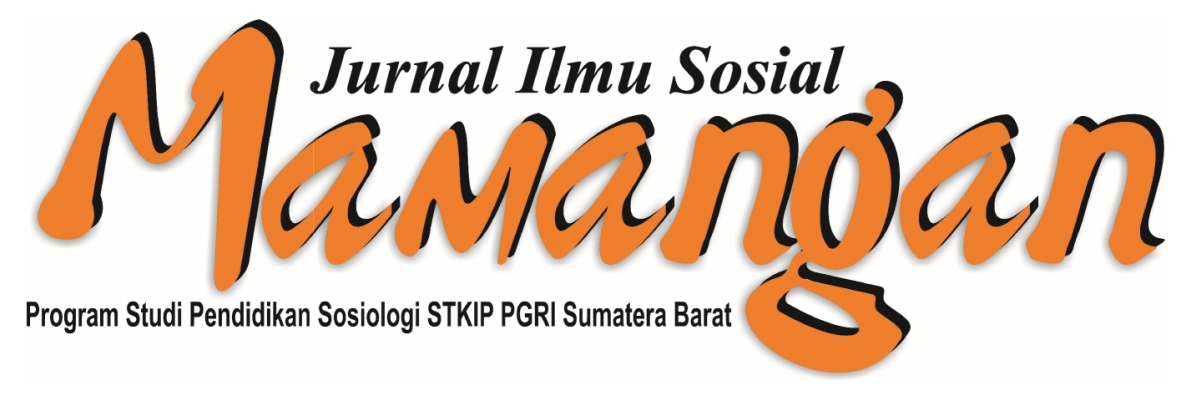

Jurnal Ilmu Sosial Mamangan

Volume 5, Nomor 2, Juli-Desember 2016

Upaya Keluarga Dalam Penyembuhan Pasien Penyakit Jiwa; Studi Pada Pasien Penyakit Jiwa di RSJ HB. Sa'anin Padang

Penulis :Yenni Melia

Sumber : Jurnal Ilmu Sosial Mamangan, Volume 5, Nomor 2, Juli-Desember 2016

Diterbitkan Oleh : Laboratorium Pendidikan Sosiologi, STKIP PGRI Sumatera Barat

Untuk Mengutip Artikel ini :

Melia, Yenni, 2016. Upaya Keluarga Dalam Penyembuhan Pasien Penyakit Jiwa; Studi Pada Pasien Penyakit Jiwa di RSJ HB. Sa'anin Padang. Jurnal Ilmu Sosial Mamangan, Volume 5, Nomor 2, Juli Desember 2016: 102-112.

Copyright (C) 2016, Jurnal Ilmu Sosial Mamangan

ISSN : 2301-8496 (Print), ISSN : 2503-1570 (Online)

Laboratorium Pendidikan Sosiologi STKIP PGRI Sumatera Barat 


\title{
Upaya Keluarga Dalam Penyembuhan Pasien Penyakit Jiwa; Studi Pada Pasien Penyakit Jiwa di RSJ HB. Sa'anin Padang
}

\author{
Yenni Melia \\ Program Studi Pendidikan Sosiologi, STKIP PGRI Sumatera Barat \\ Email : yeni.melia@yahoo.com
}

\begin{abstract}
Madness is a symptom of a disease caused by psychiatric symptoms. Many factors become the cause of insanity, therefore need many approaches in healing. The process of healing the family involvement factor is an important factor. This study discusses family efforts to support the cure of psychiatric patients at psychiatric hospital of Prof. HB. Sa'anin. The research was conducted by qualitative method by following the steps suggested by Miles and Huberman. Data were collected using observation techniques, interviews and documentation studies. The informant consists of the main informant, the family of the mental illness patient and the supporting informant, the hospital officer. The results reveal the efforts provided by the family in the healing of mental illness patients, among others, by providing motivation to return to normal conditions. Another factor that causes healing is the economic and educational factor of family members. What is unique is that ethnic role factors have an effect on patient healing. Strategies that can be done to involve the family in healing is to establish mutual communication and the resignation nature of family members.
\end{abstract}

Keywords: Family Healing, Psychiatric Symptoms Patient, Madness.

\begin{abstract}
ABSTRAK
Gila adalah gejala penyakit yang disbabkan oleh gejala kejiwaan. Banyak faktor yang menjadi penyebab kegilaan, oleh karena itu perlu banyak pendekatan dalam penyembuhannya. Dalam proses penyembuhan tersebut faktor keterlibatan keluarga adalah faktor penting dalam proses penyembuhan. Studi ini membahas tentang upaya keluarga dalam mendukung penyembuhan pasien sakit jiwa di rumah sakti jiwa Prof. HB. Sa'anin. Penelitian dilakukan dengan metode kulitatif dengan mengikuti langkah-langkah yang disarankan Miles dan Huberman. Data dikumpulkan dengan menggunakan teknik observasi, wawancara dan studi dokumentasi. Informan penelitian terdiri dari informan utama, yaitu keluarga pasien penyakit jiwa dan informan pendukung, yaitu petugas rumah sakit. Hasil penelitian mengungkapkan upaya yang diberikan oleh keluarga dalam penyembuhan pasien penyakit jiwa antara lain dengan memberikan motivasi untuk kembali ke kondisi normal. Faktor lain yang menjadi penyebab kesembuhan adalah faktor ekonomi dan pendidikan anggota keluarga. Yang unik adalah, faktor peran etnis ikut berpengaruh dalam upaya penyembuhan pasien. Strategi yang dapat dilakukan untuk melibatkan keluarga dalam penyembuhan adalah dengan menjalin komunikasi timbal balik dengan sesama anggota keluarga dan sifat pasrah anggota keluarga.
\end{abstract}

Kata Kunci: Pengobatan Oleh Keluarga, Pasien Penyakit Jiwa, Penyakit Jiwa. 


\section{PENDAHULUAN}

Dewasa ini berbagai persoalan dihadapi oleh keluarga yang tidak hanya disebabkan hubungan ayah atau ibu yang kurang harmonis tetapi juga bisa karena persoalan ekonomi dengan tingginya kebutuhan yang harus dipenuhi. Berbagai persoalan tersebut mengakibatkan masing-masing anggota keluarga tidak dapat memenuhi serta melaksanakan peran yang diharapkan, yang kadangkala mengakibatkan anggotanya mengalami stress dan akhirnya sakit jiwa. Penyakit jiwa bagi sebagian masyarakat di pandang memalukan dan tak jarang anggota keluarga yang terkena sakit jiwa diisolasi dari pergaulan. Lebih menyedihkan lagi mereka dipasung serta dibiarkan hidup bebas di jalan-jalan. Masyarakat sering menyebut orang sakit jiwa dengan istilah orang gila. Mereka kadang-kadang menjadi objek perhatian atau olok-olokkan dan tidak jarang masyarakat bersikap sembrono, serta tidak bertanggung jawab terhadap kesembuhan penyakit yang dideritanya (Foucault, 2002). Seorang pasien penyakit jiwa atau orang gila tersebut dapat sembuh secara total tidak hanya dengan bantuan dokter atau para medis tetapi lebih banyak peran keluarga, karena keluarga merupakan tempat awal dimana pasien penyakit jiwa tumbuh dan berkembang untuk melanjutkan kehidupannya.

Perawatan terhadap anggota keluarganya yang mengalami penyakit jiwa adalah rumah sakit jiwa, dengan tujuan membantu keluarga mengembalikan fungsi sosial pasien dan sembuh secara total. Pelayanan dan pengobatan yang diberikan kepada pasien berlangsung seumur hidup karena pasien sakit jiwa berbeda dengan penderita penyakit lain. Salah satu rumah sakit jiwa yang merawat pasien sakit jiwa di Sumatera Barat adalah Rumah sakit jiwa Prof. HB. Sa'anin Padang. Anggota keluarga yang menderita sakit jiwa dimasukkan ke rumah sakit jiwa karena keluarga tidak mampu lagi mengurus atau mengontrol prilaku pasien yang dapat membahayakan keluarga dan masyarakat.

Berdasarkan grand tour ditemui berbagai kegiatan penyembuhan yang dilakukan terhadap pasien dari pengobatan secara medis sampai pada kegiatan rutin atau terapi penyembuhan (non medis), misalnya terapi musik, terapi olahraga yang dilakukan setiap pagi. Persoalan yang sering ditemui rumah sakit jiwa Prof. HB. Sa'anin Padang dalam pembinaan, pelayanan terhadap pasien adalah: (1) keluarga tidak melakukan kunjungan kembali, (2) keluarga banyak tidak bertanggung jawab setelah pasien dimasukkan ke rumah sakit, (3) kurangnya perhatian dan kasih saying keluarga terhadap pasien, (4) tidak adanya motivasi keluarga untuk mendorong pasien sembuh, (5) keluarga malu memiliki pasien penyakit jiwa. Sehingga pasien yang kurang mendapatkan dukungan dari keluarga yang dirawat di rumah sakit jiwa Prof. HB. Sa'anin menyebabkan penyembuhannya mengalami hambatan. Tidak jarang ditemukan pasien yang telah sembuh dirawat di rumah sakit setelah dikembalikan ke keluarga kambuh lagi dan akhirnya kembali lagi ke rumah sakit jiwa Prof. HB. Sa'anin. Berdasarkan fenomena tersebut diatas, menarik ditelusuri lebih lanjut melalui penelitian bagaimana upaya keluarga dalam penyembuhan pasien penyakit jiwa.

\section{METODE}

Penelitian ini menggunakan pendekatan kualitatif yaitu berusaha mengungkapkan upaya keluarga dalam memecahkan permasalahan terhadap penyembuhan pasien penyakit jiwa dirumah sakit jiwa.Lokasi penelitian adalah Rumah Sakit Jiwa Prof. $\mathrm{Hb}$. Sa'anin Padang. Penelitian ini menggunakan sampel bertujuan (purposive sample), sampel atau informan dalam penelitian ini terdiri-dari informan utama yaitu: 10 keluarga pasien penyakit jiwa sedangkan informan pendukung terdiri - dari dokter, perawat, pegawai rumah sakit dan psikolog yang berjumlah 4 orang. Teknik pengumpulan data yang digunakan yaitu: Wawancara, observasi dan dokumentasi.

Data yang diperoleh dalam penelitian ini dianalisis dengan metode yang dikemuka oleh Miles dan Huberman ( 1992 ) dengan langkah - langkah, yaitu (1) reduksi data, (2) penyajian data, (3) penarikan kesimpulan. Untuk penjamin keabsahan data, penelitian ini mengacu pada standar kredibilitas yang diperkenalkan oleh Lincoln dan Guba (Faisal, 1990). 


\section{KEGILAAN DAN PERAN KELUARGA}

Peranan merupakan aspek dinamis kedudukan (status), apabila seseorang melaksanakan hak dan kewajiban sesuai dengan kedudukan maka dia menjalankan suatu peranan. Peranan dan kedudukan tak dapat dipisahkan keduanya saling ketergantungan, tak ada peranan tanpa kedudukan atau kedudukan tanpa peranan sehingga lebih berat pada pelaksanaan fungsi, penyesuaian diri dan sebagai suatu proses seseorang dalam masyarakat serta menjalankan suatu peranan (Soekanto, 1990). Keluarga adalah kelompok primer yang paling penting di dalam masyarakat karena terbentuk dari sebuah group sosial yang terkecil dimana terjadi perhubungan laki-laki dan perempuan yang berlangsung lama untuk membesarkan anak-anaknya (Hartono, 1999). Dalam sistem keluarga terikat akan hubungan kekerabatan yang menyelenggarakan pemeliharaan anak dan kebutuhan manusiawi tertentu lainnya seperti pendidikan (Rahayu, 2016).

Intisari pengertian keluarga adalah : 1) Keluarga merupakan kelompok sosial kecil yang umumnya terdiri dari ayah, ibu dan anak serta kadang kala anak yang sudah menikah, 2) Hubungan sosial di antara anggota keluarga yang relative tetap dan didasarka atas ikatan darah, perkawinan dan adopsi, 3) Hubungan antar anggota keluarga yang dijiwai oleh suasana kasih saying dan rasa tanggung jawab, 4) Keluarga adalah tempat untuk merawat, memelihara dan melindungi anak dalam rangka sosialisasi agar anggota keluarga dapat mengendalikan diri dari hal yang dapat merusak anggota keluarga sendiri dan mampu berjiwa sosial (Khairudin, 1997). Beberapa fungsi keluarga adalah sebagai berikut :

a. Fungsi pengaturan seksual, keluarga adalah lembaga pokok yang merupakan wahana bagi masyarakat untuk mengatur dan mengorganisasikan kepuasan keinginan seksual.

b. Fungsi reproduksi, untuk memproduksi atau melanjutkan keturunan sehingga anak dapat lahir dan ada pula sebagian masyarakat yang mana tanpa ada ikatan.

c. Fungsi sosialisasi, pemberian model pada anak bagaimana menjadi seorang yang mampu berinteraksi dan bergaul dengan dunia luar.

d. Fungsi afeksi, Salah satu kebutuhan dasar manusia adalah kebutuhan akan kasih sayang atau rasa dicintai. Pandangan psikiatrik berpendapat bahwa penyebab utama gangguan emosional, masalah prilaku dan kesehatan fisik adalah ketiadaan cinta yakni kurangnya kasih sayang dan tidak merasa dicintai.

e. Fungsi penentuan status, dalam memasuki sebuah keluarga seseorang mewarisi suatu rangkaian status misalnya sebagai anak.

f. Fungsi perlindungan, dalam setiap masyarakat keluarga memberikan perlindungan fisik, ekonomis dan psikologis bagi seluruh anggotanya.

g. Fungsi ekonomis, para anggota keluarga bekerja sama sebagai tim untuk menghasilkan sesuatu penghidupan yang lebih baik (Hartono, 1999).

Berdasarkan uraian tersebut bahwa fungsi keluarga lebih dominan fungsi phisikis anggotanya karena sangat penting untuk membantu tumbuh dan berkembangnya seseorang dalam masyarakat. Pelaksanaan rehabilitasi bagi pasien penyakit jiwa merupakan usaha penyembuhan atau pengobatan yang dilakukan oleh keluarga dengan bantuan rumah sakit agar pasien dapat sembuh secara total dan dapat melaksanakan fungsi sosialnya dalam masyarakat.

Dali Gulo mengatakan bahwa program adalah suatu prosedur untuk memecahkan satu masalah. Dia merupakan suatu penyusunan perencanaan yang harus dipelajari melalui tahap langkah-langkah pendek dair kerangka-kerangka yang menentukan respons aktif dan umpan balik (Kartini, 1997). Evaluasi adalah penilaian tentang bagaimana program dijalankan, apakah proses dan dampaknya sudah sesuai dengan yang diharapkan, serta mengecek faktorfaktor penghambat yang dihadapi, dan faktor-faktor pendukung yang dimiliki, untuk mencapai tujuan (Firdaus, 2016).

Pengertian di atas dapat diartikan bahwa program merupakan suatu metode yang digunakan untuk memecahkan suatu masalah bagi seseorang yang mengalami penyakit jiwa 
atau kondisi mental yang tidak normal dan perlu proses pengobatan. Salah satu usaha bidang kesehatan yang digunakan oleh rumah sakit jiwa adalah rehabilitasi. Pasien penyakit jiwa merupakan seseorang yang tak dapat hidup dalam tatanan masyarakat yang layak seperti masyarakat lainnya, umumnya mereka tidak dapat berinteraksi, tidak mengenal lingkungan dan kadang kala ada pola tingkah laku yang merusak serta membahayakan anggota keluarga dan masyarakat tempat mereka tinggal.

Kegilaan merupakan kondisi fisik kemanusiaan paling rendah yang padanya kekuatan gaib tinggal dalam inkarnasi untuk mewujudkan bahwa tidak ada kekejaman dalam diri manuasia yang tidak dapat dibebaskan atau diselamatkan dari pengaruh kekuatan gaib tersebut (Foucault, 2002). Seseorang yang dikatakan sakit jiwa atau orang gila adalah seseorang yang kehilangan immoralitas dan irrasionalitas. Adapun ciriciri seseorang yang mengalami penyakit jiwa (Depkes RI, 1991) adalah :

1. Memiliki hambatan mobilitas fisik dalam melaksanakan kegiatan seharihari.

2. Memiliki hambatan atau kecanggungan mental psikologis yang menyebabkan rasa rendah diri, isolatif, kurang percaya diri, rendahnya kemauan dan kecintaan kerja serta kurangnya tanggung jawab terhadap masa depan diri, keluarga maupun masyarakat.

3. Memiiki hambatan dan gangguan dalam keterampilan kerja produktif.

4. Memiliki hambatan dalam melaksanakan kegiatanyang tidak terlihat pada hal sebagai berikut:

a. Tidak memiliki kemauan dan kemampuan bergaul dengan wajar.

b. Tidak berkemauan dan berkemampuan berkomunikasi secara wajar.

c. Tidak berkemauan dan berkemampuan dalam melaksanakan kegiatan masyarakat dan lebih banyak bergantung pada orang lain.

5. Rawan kondisi sosial ekonomi keluarga.

6. Usia produktif atau secara fisik Nampak kuat.

Dari uraian ciri-ciri tersebut menggambarkan bahwa seseorang yang mengalami penyakit jiwa mempunyai hambatan-hambatan terutama sekali hambatan mental sehingga mengganggu jiwanya dan aktivitas mereka secara normal. Sehat atau kesehatan adalah keadaan yang bebas dari penyakit cacat dan kelemahan yang memungkinkan setiap individu hidup produktif secara sosial ekonomi dan intelektual (Sukarni, 1994). Semua warga berhak memperoleh derajat kesehatan yang optimal, agar dapat bekerja dan hidup layak sesuai dengan martabat manusia tanpa ada tekanan dari berbagai pihak. Beberapa factor penentu derajat kesehatan: (1) faktor bawaan. (2) faktor pelayanan. (3) faktor prilaku. (4) faktor lingkungan antara lain : fisik, biologik dan kemasyarakatan (Sukarni, 1994). Menurut UU No.9 thn 1960 sehat adalah keadaan yang meliputi kesehatan badan, rohani (mental dan sosial dan bukan hanya keadaan yang bebas dari penyakit, cacat dan kelemahan).

\section{KLASIFIKASI PENYAKIT JIWA YANG DI DERITA PASIEN}

Klasifikasi pasien yang dirawat di Rumah Sakit Jiwa yang mendapat pelayanan, pengobatan mengalami berbagai macam penyakit kejiwaan. Ini dapat dilihat pada tabel berikut:

Tabel :

Jumlah diagnose penyakit pasien penyakit jiwa di rumah sakit jiwa Prof. HB. Sa'anin Padang Des - Maret 2016

\begin{tabular}{|c|l|c|c|}
\hline No & Diagnosa & Jumlah & \% \\
\hline 1 & $\begin{array}{l}\text { Schizophrenia } \\
\text { paranoid }\end{array}$ & 724 org & $73,9 \%$ \\
\hline 2 & $\begin{array}{l}\text { Episode kini manic } \\
\text { dengan gejala } \\
\text { psikotik }\end{array}$ & 145 org & $\begin{array}{c}14,79 \\
\%\end{array}$ \\
\hline 3 & $\begin{array}{l}\text { Gangguan kepribadian } \\
\text { dan prilaku akibat } \\
\text { penyakit kerusakan } \\
\text { dan otak }\end{array}$ & 40 org & $4,08 \%$ \\
\hline 4 & $\begin{array}{l}\text { Schizophrenia } \\
\text { hebefrenik }\end{array}$ & 24 org & $2,44 \%$ \\
\hline 5 & $\begin{array}{l}\text { Episode kini depresif } \\
\text { berat dengan gejala } \\
\text { psikotik }\end{array}$ & 15 org & $1,53 \%$ \\
\hline 6 & $\begin{array}{l}\text { Schizophrenia yang } \\
\text { tak ditentukan }\end{array}$ & 12 org & $1,22 \%$ \\
\hline 7 & $\begin{array}{l}\text { Episode kini depresif } \\
\text { ringan / sedang }\end{array}$ & 11 org & $1,12 \%$ \\
\hline
\end{tabular}




\begin{tabular}{|c|c|c|c|}
\hline 8 & $\begin{array}{l}\text { Episode kini manik } \\
\text { tanpa gejala psikotik }\end{array}$ & 9 org & $0,91 \%$ \\
\hline Jumlah & 980 org & 100 \\
\hline
\end{tabular}

Sumber: Diolah data dari RSJ Prof. HB. Sa'anin Padang

Berdasarkan tabel diatas di peroleh keterangan bahwa penyakit yang banyak dialami adalah schizophrenia paranoid 724 orang ( 73,9\%), episode kini manic dengan gejala psikotik 145 orang ( $14,79 \%$ ), gangguan kepribadian dan prilaku akibat penyakit kerusakan otak 40 orang ( $4,08 \%$ ), schizophrenia hebefrenik 24 orang $(2,44 \%)$, episode kini depresif berat dengan gejala psikotik 15 orang ( $1,53 \%)$, schizophrenia yang tak ditentukan 12 orang ( $1,22 \%$ ), episode kini depresif ringan / sedang 11 orang $(1,12 \%)$, episode kini manic tanpa gejala psikotik 9 orang $(0,91 \%)$. Dari tabel diatas tergambar penyakit pasien sakit jiwa yang banyak adalah Schizofrenia paranoid yaitu penderita mengalami delusi, halusinasi yang terus berganti-ganti coraknya dan tidak teratur serta kacau balau. Umumnya pasien schizophrenia paranoid sangat bermusuhan terhadap siapapun. Sedangkan penyakit kejiwaan episode kini manik tanpa gejala psikotik dan episode kini depresi ringan/sedang karena penyakit tersebut masih dalam taraf ringan dan tidak terlalu perlu untuk dirawat inapkan dirumah sakit.

\section{UPAYA KELUARGA DALAM MENDUKUNG PENYEMBUHAN PASIEN PENYAKIT JIWA}

Peran anggota keluarga dalam memberikan motivasi kepada pasien sakit jiwa dibantu oleh anggota keluarga pasien sakit jiwa yang dilakukan oleh keluarga baik secara fisik maupun psikis. Bantuan keluarga secara fisik terhadap pasien sakit jiwa yaitu memberikan obat dan memasukan pasien kerumah sakit atau secara medis. Sedangkan secara phisikis memberikan kasih sayang, motivasi dan kunjungan rutin terhadap pasien yang berada di Rumah Sakit Jiwa Prof. HB. Sa'anin Padang.

\section{Motivasi dari Ibu dan Bapak}

Dalam masyarakat umum masih ada suatu keluarga yang terdiri dari bapak/ibu, anak yang sudah menikah dan memiliki beberapa cucu. (Hartomo:1999). Hubungan tersebut berjalan baik dan harmonis karena adanya penurunan nilai - nilai budaya, aturan agama yang mengharuskan setiap anggota keluarga saling mengasihi dan ikut merasakan penderitaan anggota dalam keluarga tersebut apalagi orang tua yang sudah melahirkan dan membarsarkan hingga mereka dewasa. Dari hasil penelitian jumlah pasien yang 299 orang, 98 orang berstatus belum kawin dan berstatus janda/duda lebih banyak dari kedua status tersebut yaitu 101 orang lebih banyak memberikan motivasi dan semangat untuk sembuh adalah peran ayah/ibu. Dengan bantuan perhatian perhatian dan bimbingan kedua orang tuanya, pasien merasa damai serta dapat melakukan aktifitas sederhana. Seorang ayah/ibu masing - masing memiliki peran yang sama dalam membesarkan dan membimbing anak - anaknya. Seorang ayah dianggap sebagai kepala keluarga yang diharapkan mempunyai sifat kepemimpinan.

Seorang pemimpin harus dapat memberikan teladan yang baik, memberikan semangat untuk berkembangnya kreatif anak. Seorang ibu berperan sebagai proses terjadinya sosialisasi awal bagi kehidupan seorang anak. Sehingga jika sianak mengalami persoalan dia akan kembali kepada ibu / bapaknya untuk memberikan perlindungan.

Hasil penelitian juga mengungkapkan peran ibu sangat menentukan karena secara psikologi hubungan ibu dengan anak tidak dapat dipisahkan walau sianak sudah bekerja dan mandiri. Hubungan tersebut tidak akan terputus apalagi jika sianak dalam keadaan sakit yang kondisinya berbeda dari penyakit masyarakat kebanyakan.

\section{Motivasi dari Suami / Istri}

Hubungan suami / istri diikat dalam status perkawinan dengan tujuan membentuk rumah tangga atau keluarga yang saling menghormati, menyayangi dan ikut merasakan setiap persoalan yang dihadapi oleh masing - masing pasangan. Ini terbukti dari hasil penelitian mengungkapkan bahwa 89 orang atau 30,90 \% berstatus kawin karena keluarga akan terasa lengkap apabila antara suami 
/ istri dan anggota keluarga lain saling menunjang, member semangat dalam menjalani kehidupan.

Hubungan suami / istri akan berjalan baik apabila masing - masing tersebut menjalankan peran suami dengan kedudukannya misalnya suami menjalankan peran sebagai bapak pencari nafkah, melindungai anggota keluarga lain, sedangkan seorang istri tidak hanya memberikan dan melayani suami ataupun istri dalam kondisi senang maupun sakit. Hasil penelitian, mengungkapkan bahwa seorang istri memasukkan suaminya ke rumah sakit tidak hanya untuk berobat tetapi ketidakmampuan untuk merawat pasien jika penyakit yang diderita pasien kambuh dan sampai pada perbuatan tindak kekerasan.

Tingkat kepedulian seorang suami tidak hanya bagaimana memberikan pengobatan agar pasien sembuh tapi juga memberikan kasih sayang, perhatian dan semangat untuk hidup berkumpul bersama anggota keluarga.

Dukungan istri walaupun kadang ia tidak mengakui suaminya yang sakit dirumah sakit tapi keluarga khususnya istri tetap memberikan perhatian dan menjenguk pasien sambil melihat perkembangan pasien. Secara medis pasien tidak dapat sembuh jika tidak didukung oleh peran dokter, psikolog dan para medis lainnya tapi juga keluarga atau orang - orang yang dekat dengan pasien.

\section{Motivasi dari Saudara}

Hubungan saudara adalah hubungan dengan kedekatan emosi yang lebih kuat diantara mereka berdua. Hubungan atau ikatan emosinya berlangsung paling lama dibandingkan hubungan persaudaraan yang lain, dapat terpisah karena status atau sudah mengalami perselisihan. Peran kakak/adik dilakukan tidak hanya karena pasien belum kawin, janda/duda dan kawin tapi karena adanya ikatan darah maupun rasa tanggung jawab yang besar terhadap saudara dekat dalam kesusahan. Untuk memberikan dukungan, motivasi dan perhatian kepada sudaranya agar dapat sembuh dan kembali berkumpul bersama keluarga. hasil penelitian,adanya kepedulian seorang adik untuk berusaha mendengar cerita, keluhan dan meluangkan waktu demi kakaknya agar dapat sembuh. Walau sebenarnya ia tidak tega melihat kondisi klien yang dikurung dijeruji besi seperti tahanan.

Dapat disimpulkan bahwa motivasi yang diberikan oleh kakak/adik sangat membantu dalam penyembuhan pasien sakit jiwa. Dengan saling mendengar dan memberikan pertolongan kala diantara anggota keluarga dalam kesusahan, walau orang tua tidak berdaya untuk membantu.

\section{FAKTOR PENDUKUNG PENYEMBUHAN PASIEN PENYAKIT JIWA}

Masing-masing setiap peran yang dilakukan oleh anggota keluarga antara lain: ibu/bapak, suami/istri, kakak/adik dalam melakukan kunjungan dan motivasi ke Rumah Sakit di pengaruhi beberapa faktor pendukung yaitu :

\section{Faktor Ekonomi Keluarga}

Kebutuhan ekonomi dalam suatu keluarga merupakan kebutuhan yang utama sebagai alat untuk melanjutkan kehidupan yang lebih baik. Dalam masyarakat secara luas ada pola masyarakat yang taraf ekonominya menengah keatas dan ada masyarakat atau keluarga yang ekonominya menengah ke bawah. Pasien yang ditempatkan dirumah sakit jiwa juga ada yang dikelas utama ( VIP ) sampai kelas III serta keluarga yang peduli dengan pasien. Tetapi tidak memiliki dana atau biaya untuk mengobati pasien maka anggota keluarga menempatkan pasien pada bangsal kelas III dengan bantuan biaya pemerintah. Di lihat dari ekonomi anggota keluarga pasien ada beberapa faktor yang mempengaruhi yaitu:

\section{Bentuk Pekerjaan Keluarga Pasien}

Pekerjaan keluarga pasien penyakit jiwa bermacam-macam ada dari pedang, petani, ABRI dan PNS / pensiunan dan lain-lain. Tingkat kepedulian keluarga tidak tergantung dari PNS atau petani. Keluarga Jum (klien) yang bapaknya bekerja sebagai petani sawit dikebun orang, dengan kehidupan yang sederhana. Orang tua jum rutin 1 kali sebulan melihat atau mengontrol perkembangan prilaku 
klien, dengan membawa makanan roti atau rokok. Dari hasil informasi petugas rumah sakit dan data yang didapatkan selama peneli berada dirumah sakit jiwa ada juga keluarga yang orang tua maupun suaminya bekerja sebagai Pegawai Negeri Sipil (PNS) maupun pensiunan.

\section{Tingkat Penghasilan Keluarga Pasien}

Tingkat penghasilan keluarga pasien rumah sakit jiwa menurut informasi dari beberapa keluarga yagn mengunjungi pasien secara rutin bermacam-macam sesuai dengan mata pencaharian keluarga pasien. Dari wawancara di dapat gambaran anggota keluarga yang selalu mengunjungi pasien mendapat gaji perbulan maupun harian yang berkisar antara Rp. 20.000 sampai Rp. 50.000. Sedangkan gaji Rp. 700.000 sampai Rp. 800.000 perbulan. Ada juga keluarga yang memiliki penghasilan perbulan namun tidak peduli. Dari petugas rumah sakit didapat data dan penulis juga mengecek kebenarannya dari buku status klien bahwa bapak klien adalah pensiunan PNS dan klien sendiri sudah bersuami yang juga PNS golongan III D dikantor gubernur Padang. Didapat juga informasi bahwa pasien mengalami penyakit jiwa sudah bersifat turunan yang mana ibu kandung dan kakak klien juga bekas rawat inap dirumah sakit jiwa Prof. HB. Sa'anin Padang dan sekarang tinggal dikampungnya yaitu : Solok. Ketidak pedulian suami klien terhadap klien karena tidak ingin punya istri yang mengalami penyakit jiwa dan malu. Pada saat klien di rumah sakit status klien adalah janda, klien membina rumah tangga waktu klien duduk dibangku kuliah semester IV di Sekolah Tinggi Bahasa Asing (STBA) prayoga Padang karena klien mengalami penyakit jiwa maka suami tidak mampu lagi mengontrol prilaku klien maka ia menceraikannya. Selain itu penghasilan tidak mempengaruhi peran dan tanggung jawab keluarga terhadap kesembuhan pasien karena keluarga yang tidak mampu diberi pelayanan gratis atau dibiayai oleh pemerintah, keluarga hanya mengusahakan biaya untuk ongkos dan kebutuhan keluarga jika ingin melihat pasien dirumah sakit. Keluarga yang memiliki penghasilan tetap yaitu sebagai Pegawai Negeri Sipil (PNS) tapi ia malu dan tidak peduli pada pasien, namun ada keluarga yang kekurangan serta hanya cukup untuk kebutuhan hidup sehari-hari mampu memberikan perhatian pada pasien.

\section{Faktor Pendidikan Keluarga Pasien}

Peran keluarga dalam membantu penyembuhan pasien penyakit jiwa juga tergantung dari tingkat faktor pendidikan keluarga pasien. Dengan pengetahuan yang dimiliki oleh keluarga pasien diharapkan mampu memberikan pelayanan dan membantu pasien untuk dapat kembali secara normal ke tengahtengah masyarakat. Dari hasil penelitian didapat gambaran bahwa tingkat pendidikan keluarga pasien ada Sarjana, SMA, SMP dan SD. Tingkat pendidikan keluarga yang banyak adalah tamat Sekolah Dasar (SD) dengan jumlah 87 orang atau 30,20\%an tidak terlalu jauh dengan jumlah keluarga pasien yang tamat Sekolah Menengah Pertama (SMP) 86 orang atau 29,86\%. Keluarga yang berpendidikan sarjana juga ada tapi tidak terlalau mendukung terhadap penyembuhan pasien penyakit jiwa hanya $1,04 \%$. Ada keluarga yang berpendidikan tinggi, dengan keluarga yang mapan meletakkan pasien pada kelas VIP dengan fasilitas yang lengkap.

Tetapi lebih banyak keluarga pasien yang peduli terhadap pasien adalah keluarga yang pendidikan orang tuanya rendah tapi anak-anaknya minimal SMP dan ada pula sarjana.

\section{Faktor Peran Etnis}

Di rumah sakit jiwa Prof. HB. Sa'anin pasien tidak hanya etnis atau keturunan Minangkabau walau letaknya di Sumatera Barat tapi juga ada etnis Cina dan Batak tapi jumlahnya tidak sebanyak keturunan Minang.

Peran yang ditampilkan oleh masingmasing etnis keluarga berbeda-beda 
namun pola pikir masyarakat tentang pasien penyakit jiwa adalah sama yaitu suatu penyakit yang tidak bisa sembuh dan aib bagi keluarga.

Hasil penelitian tergambar jumlah pasien yang berasal dari Sumatera Barat dalam rentang 5 tahun belakang berjumlah 5274 atau 99,2\%. Masyarakat minang yang tinggal di Sumatera Barat tidak hanya asli orang minang tapi juga ada keturunan non minang. Gambaran bentuk peran keluarga masing-masing etnis dalam mendukung penyembuhan pasien penyakit jiwa di Rumah Sakit Jiwa adalah:

\section{Motivasi Etnis atau keturunan Minangkabau}

Menurut HB Saanin (1983:206). Banyaknya orang Minang dahulu mengalami penyakit jiwa disebabkan oleh kondisi Sosio, kultural dan hubungan matrilineal yang mana kedudukan perempuan di rumah gadang serta pola asuh anak yang lebih memberati kaum ibu.

Ini disebabkan oleh suami pergi merantau. Dari kondisi tersebut yang mengikat dan memberarti secara psikis bagi masyarakat Minang. Di rumah sakit jiwa peran keluarga etnis Minang kebanyakan mereka yang ekonomi menengah ke atas menempat pasien di kelas VIP, I, II maupun di kelas III yang pembayarannya murah. Selain menempatkan pasien sesuai dengan ekonomi keluarga, mereka juga rutin dan peduli dalam memberikan perhatian kepada pasien.

Walaupun keluarga bertempat tinggal jauh dari rumah sakit dan keberperanan keluarga tidak hanya membantu penyembuhan pasien secara obat-obatan (farmakoterapi) tetapi juga dengan bantuan non medis.

\section{Motivasi etnis atau keturunan non- Minang}

Rumah sakit jiwa Prof. HB. Sa'anin berada di Sumatera Barat yang pasiennya juga ada pasien non Minang yaitu cina. Tetapi pasien yang ada pada saat penulis melakukan penelitian adalah Cina terdiri dari 1 orang laki- laki di VIP 2 orang laki-laki dan perempuan di tempatkan oleh keluarga pada kelas II serta ada 5 orang di kelas 3.2 (dua) orang dikirim oleh olah Departemen Sosial yang waktu menggelandang di depan kantor tersebut dan tidak mengetahui alamat pasien, sedangkan yang 3 orang dikirim oleh keluarga.

Dari hasil penelitian penulis dapat disimpulkan bahwa keluarga pasien etnis atau keturunan non minang menyerahkan seutuhnya kesembuhan klien kepada pihak rumah sakit dan keluarga hanya berfikir biaya klien dirumah sakit. Memberikan perhatian atau mengikat hubungan psikologis antara keluarga dengan klien tidak menjadi suatu kebutuhan yang utama bagi keluarga klien. Keluarga menganggap bahwa pasien penyakit jiwa bisa sembuh cukup dengan bantuan para medis dan kalau keluarga berperan juga akan merusak keturunan keluarga selanjutnya karena malu atau aib.

\section{FAKTOR PENYEBAB BERKURANGNYA PERAN KELUARGA TERHADAP PENYEMBUHAN PASIEN PENYAKIT JIWA.}

Dalam membantu penyembuhan pasien penyakit jiwa ada beberapa permasalahan yang dihadapi. Masalah tersebut ada yang mudah diatasi (sesuai dengan kondisi aktual yang ada), ada juga permasalahan yang sulit dalam mencarikan solusinya. Diantar masalah-masalah yang menjadi kendala utama sebab berkurangnya peran keluarga dalam membantu penyembuhan pasien penyakit jiwa sebagai berikut:

\section{Status Sosial Ekonomi Keluarga.}

Keadaan ekonomi keluarga pasien sakit jiwa di golongkan ekonomi menengah kebawah yang kadang kala cukup untuk memenuhi kebutuhan sehari-hari keluarga. Sehingga untuk kebutuhan menjenguk pasien tidak menjadi prioritas utama tidak hanya itu, pekerjaan orang tua atau anggota keluarga pasien yang selalu menjenguk pasien rata-rata petani atau pedangan kecil dengan tingkat penghasilan yang juga dibawah standar. Tetapi ada juga keluarga pasien yang ekonomi menengah keatas sehingga memiliki status yang tinggi pula, anggota keluarga enggan 
melihat atau mengunjungi pasien karena keluarga takut status sosialnya yang tinggi tercemar.

\section{Kendala Geografis}

Jarak atau lokasi rumah sakit tempat pasien diobati dari tempat tinggal keluarga pasien sehingga untuk menjenguk atau mengunjungi klien memakan waktu lama dan biaya yang cukup tinggi. Dengan lokasi yang jauh dari tempat tinggal keluarga mengakibatkan keluarga harus mencari waktu yang tepat agar tidak mengganggu aktivitas atau kesibukan anggota keluarga yang ingin melihat.

\section{Keluarga Malu}

Banyak pasien yang berada di rumah sakit jiwa yang anggotanya tidak peduli terhadap pasien, kadang setelah pasien berada disana tidak ada kunjungan lanjut. Sedangkan pihak rumah sakit sering memberitahukan kepada keluarga saat pasien akan dirawat (kontrak pelayanan) bahwa keluarga harus mengunjungi klien minimal 1 kali seminggu untuk melihat perkembangan dan perubahan prilaku klien apakah sudah kembali normal atau ada penyakit yang disebabkan oleh keluarga sehingga pasien mengalami penyakit jiwa. Kebanyakan keluarga tidak mengakui kalau pasien adalah anggota keluarga terdekatnya kadang pasien adalah adik/kakak kandung maupun suami/istri dikatakan oleh anggota keluarga yang menjenguk merupakan tetangganya atau saudara jauh yang kasihan dari pada pasien dibuang.

\section{Pendidikan Keluarga}

Tingkat pendidikan keluarga klien bermacam-macam ada yang ber pendidikan tamatan SD, SMP dan SMA tapi ada pula pendidikan keluarga sampai strata I dan menduduki jabatan di suatu instansi pemerintahan. Namun dilihat juga keluarga yang berpendidikan SMP kebawah tingkat kepedulian anggota keluarga terhadap klien tinggi karena ada perasaan senasib dan kasihan.

\section{STRATEGI MENINGKATKAN PERAN KELUARGA DALAM PENYEMBUHAN PASIEN PENYAKIT JIWA.}

Untuk mengatasi permasalahan yang disebabkan oleh berkurangnya peran keluarga terhadap penyembuhan pasien penyakit jiwa bukanlah persoalan yang mudah. Berbagai usaha dan strategi pendekatan yang dilakukan selama ini dengan suatu harapan bagaimana para eks pasien penyakit jiwa bisa melakukan aktivitas dan mampu berprilaku secara rasional dan wajar antara lain:

\section{Menciptakan Hubungan Yang Harmonis}

Terciptanya hubungan yang harmonis dalam keluarga membantu penyembuhan pasien sakit jiwa karena masing-masing anggota keluarga memiliki rasa bersama untuk membantu klien sembuh. Dalam keluarga tersebut tidak ada konflik, mereka hidup secara damai dan pengertian. Tanggung jawab terhadap pasien tidak dengan keterpaksaan karena pasien sakit jiwa secara nyatanya pasien bukan sakit fisik yang dapat diobati dengan mudah tapi suatu kondisi yang mana pasien perlu ketenangan dan suasana batin yang menyenangkan dan membuat klien tenang berada diantara anggota keluarga lain dari pada dirawat di Rumah Sakit Jiwa.

\section{Menumbuhkan Kepercayaan Dalam} Lingkungan Keluarga.

Adanya keyakinan anggota keluarga terhadap pasien bahwa pasien dapat sembuh apabila anggota keluarga berperan secara aktif untuk membantu pasien.

\section{Menjalin Komunikasi Timbal Balik Dengan Sesama Anggota Keluarga.}

Menjalin komunikasi timbal balik antara keluarga lain dan saling memberi informasi tentang perkembangan maupun kemunduran prilaku pasien selama dirawat di Rumah Sakit. Sehingga keluarga melakukan intropeksi terhadap dirinya masing-masing dalam keluarga untuk mencari jalan yang terbaik dalam proses penyembuhan. 


\section{Mengupayakan Totalitas Keluarga Terhadap Pasien.}

\section{Anggota}

Keluarga memberikan tanggung jawab secara totalitas kepada pasien dengan menyediakan waktu kapan pasien akan berobat dan berbagai aktifitas lainnya.

\section{Sifat pasrah anggota keluarga}

Setiap keluarga harus menyadari bahwa persoalan yang datang pada seseorang tidak harus memandang, apakah keluarga tersebut kaya/miskin, berpendidikan/tidak berpendidikan. Tapi setiap persoalan tersebut bukan untuk dijauhi tapi untuk diterima dengan mencari jalan keluarnya. Begitupula bagi keluarga pasien sakit jiwa bukan suatu penyakit yang harus diisolasi tapi harus dilakukan dengan pendekatan dan kasih sayang dari anggota keluarga lain. Pengobatan pasien tidak hanya obat tapi bagaimana saat keluarga memberikan arahan kepada pasien kala pasien sakit jiwa tersebut dalam kondisi kambuh.

\section{PEMBAHASAN}

Berdasarkan hasil penelitian ditemukan peran keluarga dalam membantu penyembuhan pasien penyakit jiwa di rumah sakit jiwa Prof. HB. Sa'anin Padang sangat membantu sehingga pasien dapat sembuh dan bersosialisasi kembali kedalam keluarga. Peran keluarga tersebut tidak hanya menempatkan pasien pada bangsal atau kelas yang bagus tapi bagaimana keluarga memberikan waktu yang cukup kepada pasien untuk berkomunikasi dan bercerita tentang hal-hal kecil yang ada dalam keluarga selama pasien di Rumah Sakit Jiwa.

Pelayanan dan pengobatan yang diberikan oleh rumah sakit sudah cukup bagus dari pengobatan medis secara fisik kepelayanan atau penyembuhan secara psikis. Kegiatan medis seperti memberikan obat dengan teratus, pemeriksaan kesehatan gigi dan bantuan terapi lain, sedangkan penyembuhan secara psikis rumah sakit memberikan ceramah agama, kegiatan pembinaan bakat dan olah raga. Tetapi juga peran keluarga dalam membantu mengembalikan ingatan dan kemampuan klien tentang anggota keluarga, aktivitas klien sebelum klien mengalami penyakit jiwa.
Sesuai dengan apa yang dijelaskan oleh Redclife Brown tentang fungsional structural salah satu isinya adalah : hubungan kekeluargaan merupakan sistem yang saling keterkaitan, yang mana anggota keluarga yang satu dengan yang lainnya dalam keluarga tersebut saling mengikat dan terikat secara sendirinya(Duncan, 1984). Dengan keterikatan tersebut masing-masing anggota keluarga ikut merasakan apa yang dirasakan oleh anggota keluarga yang lain atau pada saat anggota keluarga yang satu sakit semua anggota yang lain juga sakit.

Peran anggota keluarga dari pihak ayah/ibu dilihat cukup berperan karena adanya kepedulian ayah/ibu untuk membantu klien sembuh, walau dengan usia mereka yang sudah tua. Dari apa yang dikatakan oleh Juli Sumirat (1994:5) sembuh adalah suatu kondisi dimana seseorang atau masyarakat yang sudah terbebas dari penyakit yang dialaminya baik secara fisik maupun non fisik dalam arti tidak ada tekanan lagi. Dengan bantuan ayah/ibu dapat membuat klien kembali kepada fisik maupun non fisik yang sehat tanpa ada tekanan atau bayangan yang menakutkan sehingga klien dapat berinteraksi secara baik. Tetapi ada peran anggota keluarga yang kurang dan kadang tidak peduli yaitu peran suami/istri, ini karena suami/istri tidak kuat lagi mengurus klien dan malu namun kepedulian peran kakak/adik sama besarnya dengan peran ayah/ibu karena adanya hubungan sedarah kakak/adik yang mengikat diantara klien dirumah sakit jiwa.

Dari segi ekonomi keluarga pasien penyakit jiwa yang dilihat dari pekerjaan anggota keluarga pasien umumnya petani dan buruh dengan tingkat penghasilan juga dibawah rata-rata tapi kepedulian keluarga cukup baik. Ada keluarga pasien selain petani seperti PNS dan pensiunan. Keluarga tersebut bisa dikatakan tidak pernah mengunjungi klien selain mengantarkan klien kerumah sakit. Kalau faktor pendidikan keluarga tidak terlalu berpengeruh keluarga yang tidak berpendidikan mereka aktif Menurut teori Talcott Parsons mengenai tindakan social kesistem social inti pemikirannya bahwa : 1) tindakan itu diarahkan pada tujuannya 2) tindakan terjadi dalam suatu situasi dimana beberapa elemennya sudah pasti sedangkan elemen-elemen lainnya digunakan oleh yang bertindak sebagai alat menuju tujuan 3 ) 
secara normatif tindakan itu diatur sehubungan dengan penentuan alat dan tujuan. Dari teori tesebut bahwa keluarga sebagai alat dan tindakan untuk membantu agar apa yang menjadi tujuan rumah sakit mengembalikan pasien sehat dengan beberapa elemen yaitu yang terdiri dari anggota keluarga dan mengenyampingkan persoalan ekonomi serta hal yang tidak penting yaitu malu. Secara nurani pasien yang mengalami penyakit jiwa masih merupakan bahagian dari keluarga tersebut dan mereka tidak pernah menyangka kalau suatu saat klien akan sakit sehingga memberarti anggota keluarga yang lain.

Sesuai dengan apa yang dikatakan oleh Harton mengenai peran. Peran merupakan prilaku yang diharapkan dari seseorang yang mempunyai status. Status disini bisa sebagai orang tua, sumi/istri, kakak/adik apabila masing-masing tersebut melaksanakan hak dan kewajibannya maka sistem dalam keluarga akan berjalan dengan baik dan harmonis.

\section{KESIMPULAN}

Peran keluarga dalam mendukung penyembuhan pasien sakit jiwa sangat membantu pasien untuk bersosialisasi setelah pasien keluar dari Rumah Sakit. Dengan bantuan kunjungan rutin, bimbingan dan motivasi yang diberikan oleh keluarga saat pasien dirawat di Rumah Sakit Jiwa. Peran keluarga yang kurang umumnya dipengaruhi oleh keluarga yang malu mengunjungi pasien dan dianggap suatu aib bagi keluarga pasien penyakit jiwa. Upaya keluarga dalam mengatasi permasalahan agar keluarga dapat berperan dan membantu pasien sehingga dapat sembuh. Keluarga harus mampu secara totalitas terhadap pasien dan menjalin komunikasi serta hubungan yang baik dalam keluarga itu sendiri. Oleh karena itu, apabila ditemui salah seorang anggota keluarga yang mendapat kelainan jiwa atau penyakit jiwa sebaiknya diterima dengan hati yang lapang karena pasien penyakit jiwa pada dasarnya adalah manusia yang butuh pertolongan bukan untuk dibuang. Penting bagi Rumah Sakit Jiwa untuk lebih proaktif mendekatkan diri pada keluarga pasien sehingga tercipta komunikasi timbal balik dengan keluarga pasien.

\section{DAFTAR PUSTAKA}

Depkes RI. (1991). Pedoman Kesehatan Jiwa Bagi Petugas dan Kader Kesehatan. Direktorat Jenderal Pelayanan Medik, Depkes RI.

Duncan, M. (1984). Sosiologi Suatu Analisa Sistem Sosial. Jakarta.: Bina Aksara.

Faisal, S. (1990). Penelitian Kualitatif; DasarDasar dan Aplikasinya. Malang: YA3.

Firdaus, F. (2016). Evaluasi Proyek Pembangunan Sosial Pada Kelompok Masyarakat Kawasan Hutan Mbeliling, Kab. Manggarai Barat, NTT. Jurnal Ilmu Sosial Mamangan, 5(1), 13-22.

Foucault, M. (2002). Kegilaan dan Peradaban. Jakarta: Ikon.

Hartono, A. A. (1999). Ilmu Sosial Dasar. Jakarta: Bumi Aksara.

Kartini, K. (1997). Sosiologi Keluarga. Jakarta: Liberty.

Khairudin. (1997). Sosiologi Keluarga. Yogyakarta: Yogyakarta.

Rahayu, S. (2016). Hubungan Lingkungan Keluarga Terhadap Hasil Belajar Sosiologi Di SMA Negeri 16 Padang. Jurnal Ilmu Sosial Mamangan, 5(1), 5059.

Soekanto, S. (1990). Sosiologi; Suatu Pengantar. Jakarta: Raja Grafindo.

Sukarni, M. (1994). Kesehatan Keluarga dan Lingkungan. Jakarta: Kanisius. 